\title{
Pengobatan transfer energi sebagai salah satu metode pengobatan tradisional dalam penyembuhan penyakit
}

\section{Energy transfer medication as a traditional method in curing disease}

\author{
Annisa Novitasari \& Myrtati D. Artaria \\ Departemen Antropologi, FISIP, Universitas Airlangga, Surabaya, Indonesia
}

E-mail: myrtati@gmail.com

\begin{abstract}
Traditional medicine has been known as a widely spreaded phenomena in society as alternative or supplement for health treatment aside of modern medication. Energy-transfer medication is one kind of traditional medication that became popular in the society, no specific medicine or medical devices used in this treatment. This research performed by conducting observation and interview. Two informants as energy-transfer performer and six patients of this medication were intervewed. The research shows that the use of energytransfer medication influenced by disease severity level, knowledge and experience, faith, social behaviour, and distance.
\end{abstract}

Keywords: traditional medication, energy-transfer medication

\begin{abstract}
Abstrak
Diketahui bahwa akhir-akhir ini terdapat fenomena sosial dan budaya masyarakat mengenai pengobatan tradisional yang berkembang dan banyak digunakan oleh masyarakat sebagai alternatif atau pelengkap dari pengobatan modern. Pengobatan transfer energi sebagai salah satu jenis pengobatan tradisional, di mana tidak menggunakan alat bantu atau ramuan tertentu, semakin diminati masyarakat. Metode penelitian menggunakan observasi dan wawancara. Penelitian dilakukan di daerah Sidoarjo, Jawa Timur, di salah satu tempat pengobatan alternatif. Wawancara dilakukan pada berjumlah 2 (dua) orang sebagai pelaku pengobatan transfer energi dan 6 (enam) pasien dari pengobatan transfer energi. Hasil penelitian menunjukkan bahwa penggunaan jenis pengobatan tersebut dipengaruhi oleh tingkat keparahan penyakit, pengetahuan dan pengalaman, kepercayaan, ekonomi, sosial dan jarak.
\end{abstract}

Kata kunci: pengobatan tradisional, pengobatan transfer energi

\section{Pendahuluan}

Di Indonesia, pengobatan alternatif bukan merupakan barang langka lagi pada masa sekarang. Berbagai macam pengobatan baik menggunakan teknik tradisional warisan masa lalu ataupun yang menggunakan tenaga gaib gencar mempromosikan layanan mereka kepada masyarakat luas, baik melalui media massa maupun getok tular. Bahkan pemberitaan secara intensif mengenai pengobatan alternatif yang dilakukan oleh media massa juga dapat menarik perhatian masyarakat untuk mencoba melakukan pengobatan tersebut. Hal tersebut dapat kita ketahui pada kasus dukun cilik Ponari di Jombang, berkat pemberitaan oleh media massa yang intensif membuat masyarakat, baik berasal dari Jawa Timur maupun di luar daerah Jawa Timur berbondong-bondong ingin berobat ke Ponari karena ingin mendapatkan sentuhan magic berupa air dan batu ajaibnya.

Hal tersebut di atas sesuai dengan pernyataan Soemowerdojo (Agoes 1996:108) bahwa masyarakat masih tetap mengunjungi pengobatan tradisional, baik sebagai pengganti/altenatif atau bahkan pelengkap (komplementer) dari penggunaan pengobatan modern. Beberapa jenis pengobatan alternatif yang bermunculan dalam masyarakat, seperti: sinshe, pengobatan oleh paranormal, terapi magnetik, terapi air seni, terapi lintah, terapi tenaga dalam, prana maupun pemanfaatan ramuan obat-obatan dan sebagainya. Dalam penelitian Eisenberg et al. umumnya, jenis pengobatan alternative yang paling 
sering digunakan adalah relaksasi, chiropractic, pijat, imagery, pengobatan spiritual, program penurunan berat badan komersial, gaya hidup diet, jamu, pengobatan energi, hipnotis, homeopati, akupunktur dan folk medicine (Weiss dan Lynne 1996:219).

Terapi tenaga dalam dapat dikatakan serupa dengan pengobatan alternatif prana atau dapat dikenal dengan pengobatan transfer energi. Terapi tenaga dalam pada berbagai bangsa ini dikenal dengan berbagai nama. Bahasa Sansekerta menyebutnya prana, bahasa Ibrani menyebut prana sebagai ruah, Yunani menyebutnya peuma. Di Cina prana dikenal dengan $c h i$, di Jepang disebut $k i$, dan masih banyak lagi sebutan untuk prana bila ditinjau dari masing-masing bahasa.

Menurut Deddy Tjipto, prana adalah energi hidup yang mengalir dalam tubuh makhluk dan alam semesta. Dengan metode tertentu, prana dapat digunakan untuk membantu proses penyembuhan dan berbagai macam penyakit telah berhasil disembuhkan dengan memberikan energi ini pada tubuh yang berpenyakit (cybertech.cbn.net.id).

Lumenta (1989:95-96), menyatakan bahwa kepercayaan masyarakat terhadap suatu sistem pengobatan (baik pengobatan tradisional maupun modern) ditentukan oleh pengalaman yang dapat membuat masyarakat yakin akan keberhasilan pengobatan tersebut, biasanya lebih sulit. Penerimaan akan kenyataan sistem pengobatan medis lebih sukar, karena masing-masing sistem pengobatan (tradisional/modern) harus dapat memberikan pengalaman kerja atau menunjukkan cara-cara pengobatan yang lebih baik dan memberikan hasil yang memuaskan terhadap pasien. Tindakantindakan yang mendatangkan keberhasilan dalam usaha seseorang tersebut mempunyai kecenderungan akan diulangi kembali pada saat orang mangalami situasi yang kurang lebih serupa. Sebaliknya tindakan yang mendatangkan kegagalan memiliki kecenderungan akan dihindari. Dihadapkan pada pilihan untuk mendapatkan kesembuhan terhadap suatu penyakit, maka seseorang harus mengambil keputusan. Pengambilan keputusan selalu bersifat memilih, yakni memilih di antara berbagai alternatif yang ditawarkan untuk memecahkan masalah.

Studi tentang pengambilan keputusan terhadap penggunaan jenis pengobatan telah dilakukan oleh beberapa ahli. James C. Young (Kasniyah 1983:27) melakukan studi tentang pengambilan keputusan pada masyarakat Indian Tarascan di Mexico dengan mengajukan alternatif sumber perawatan meliputi: (1) perawatan rumah tangga; (2) perawatan yang dilakukan oleh penyembuh lokal; (3) perawatan yang dilakukan oleh practicamte (paramedic); dan (4) perawatan yang dilakukan oleh dokter dan rumah sakit. Menurut Young (Kasniyah 1983:28-33), kriteria yang dipakai untuk menyeleksi alternatif itu antara lain: (1) tingkat keparahan penyakit (gruvity); (2) pengetahuan dan pengalaman tentang cara-cara penyembuhan popular (home remedy); (3) keyakinan terhadap keefektifan pengobatan (faith); (4) kemudahan (accessibility), meliputi kemudahan biaya dan tersedianya fasilitas pelayanan kesehatan.

Naniek Kasniyah (1983:34-39) melakukan studi tentang pengambilan keputusan sumber perawatan anak balita di pedesaan jawa dengan mengajukan alternatif pengobatan berupa perawatan rumah tangga, penyembuh tradisional, paramedik, dan dokter. Faktor-faktor yang digunakan untuk memilih alternatif tersebut antara lain: (1) persepsi sosial budaya yang menyangkut tingkat keparahan penyakit, pengalaman terhadap pengobatan yang pernah digunakan sebelumnya, kepercayaan, stereotype, dan etiologi penyakit; (2) faktor ekonomi, dan (3) kemudahan akses (transportasi dan hubungan). Dyson dkk (1988:21) dalam penelitiannya tentang pola tingkah laku masyarakat dalam mencari kesembuhan di kelurahan Airlangga, Surabaya menyebutkan bahwa usaha dalam mencari kesembuhan dipengaruhi oleh tingkat keparahan penyakit, biaya pengobatan (tenaga, uang), jarak tempat tinggal dengan pelayanan kesehatan, tingkat pendidikan, dan peranan sosial dari si sakit atau keluarganya.

Walaupun terdapat berbagai jenis pengobatan alternatif yang berkembang di masyarakat, seseorang dapat menentukan jenis pengobatan yang akan digunakannya, termasuk penggunaan pengobatan transfer energi untuk menyembuhkan penyakitnya. Masalah yang dikemukakan di sini meliputi: Faktor-faktor apa yang mempengaruhi seseorang untuk berobat ke pengobatan yang menggunakan 
metode transfer energi? Bagaimana deskripsi dari proses pengobatan yang menggunakan metode transfer energi dilihat dari sudut pandang pasien dan penyembuh?

\section{Metode Penelitian}

Tulisan ini merupakan studi pengobatan transfer energi sebagai salah satu metode pengobatan tradisional. Studi dilaksanakan di salah satu pengobatan transfer energi yang berada di Kota Sidoarjo dengan informan berjumlah 2 (dua) orang sebagai pelaku pengobatan transfer energi dan 6 (enam) pasien dari pengobatan transfer energi, selain itu juga terdapat kerabat dari pasien. Studi kualitatif yang menggunakan pengamatan dan wawancara mendalam dalam pengumpulan data digunakan untuk mendeskripsikan fenomena sosial mengenai pengobatan alternative transfer energi, mulai dari proses pengobatan dilihat dari sudut pandang pasien dan penyembuh sampai faktor-faktor yang mempengaruhi pasien untuk melakukan pengobatan tersebut.

\section{Hasil dan Pembahasan}

\section{Faktor-faktor yang mempengaruhi penggunaan pengobatan transfer energi " $A$ " sebagai upaya penyembuhan}

Beralihnya pilihan seseorang dari pengobatan medis-modern ke pelayanan pengobatan tradisional yang tersedia di masyarakat dengan berbagai metode sebagai alternatif atau pelengkap dari pengobatan modern, bukanlah sebuah keputusan yang dilakukan tanpa dasar tertentu. Berdasarkan hasil penelitian yang dilakukan, ada beberapa faktor yang mempengaruhi mereka untuk memilih pengobatan transfer energi. Faktor-faktor tersebut meliputi: (1) faktor pengetahuan dan pengalaman; (2) faktor ekonomi; (3) faktor sosial; dan (4) faktor jarak. Di bawah ini, diuraikan mengenai bagaimana keempat faktor tersebut di atas memberikan pengaruh dalam pengambilan keputusan.

\section{Faktor pengetahuan dan pengalaman}

Pengambilan keputusan terhadap penggunaan sarana kesehatan bukanlah sesuatu yang diambil tanpa adanya pertimbangan tertentu. Menurut Suchman (Foster 1986:184-191), dua hal yang dianggap cukup berpengaruh dalam pengambilan keputusan terhadap pemilihan jenis pengobatan ialah pengetahuan dan pengalaman. Ketika pengetahuan seseorang terhadap penyakit sangatlah minim bisa jadi ia akan membuat keputusan memilih pengobatan yang kurang tepat untuk mengatasi penyakitnya. Sebaliknya ketika seseorang mengerti dengan baik tentang penyakit yang diderita, maka keputusankeputusan berobat yang diambil akan memberikan manfaat bagi dirinya. Hal tersebut seperti diutarakan oleh informan "E" dan "H".

Pengetahuan akan dampak dari obat-obatan medis-modern yang apabila di konsumsi terlalu sering, sekaligus dengan dosis yang berlebihan dapat mengakibatkan turunnya daya imun seseorang, sehingga nantinya dapat membuat tubuh kebal terhadap obat tersebut. Hal tersebut membuat informan "H" untuk memilih pengobatan lain sebagai alternatif dari pengobatan medis-modern. Begitu juga dengan informan "E", walaupun masih mengunjungi sarana kesehatan medis-modern untuk melakukan cek kesehatan, ia lebih memilih untuk mencari pengobatan lain di luar pengobatan medismodern dan tidak terlalu banyak mengkonsumsi obat-obatan yang didapatnya dari rumah sakit, hal tersebut dilakukannya karena anggapan bahwa terlalu banyak mengkonsumsi obat dapat merusak organ tubuh yang lain. Oleh dasar pengetahuan tersebut, membuat kedua informan mencari pengobatan lain yang dianggapnya aman serta tidak menggunakan ramuan-ramuan tertentu. Pilihan tersebut kemudian jatuh kepada pengobatan transfer energi, yang dalam cara pengobatannya selain tidak menggunakan alat, media yang digunakan hanyalah air mineral. Air mineral sebagai bagian 
yang dibutuhkan oleh tubuh tentu tidak akan berdampak apapun bagi tubuh, selain itu, air mineral juga tidak harus dibeli dari penyembuh, melainkan dapat dibawa sendiri dari rumah.

Beberapa keputusan tentang masalah kesehatan juga diambil berdasarkan pengalaman, dimana ketika seseorang merasa memiliki pengalaman buruk terhadap suatu jenis pengobatan tertentu, maka ada kecenderungan ia tidak akan menggunakan pengobatan tersebut untuk kedua kalinya (Lumenta 1989:95-96).

Faktor pengetahuan dan pengalaman dijadikan dasar oleh seseorang ketika memutuskan untuk memilih jenis pengobatan yang dianggap sesuai. Sebelum memilih, pada umumnya ia dan keluarga akan melihat seberapa parah penyakit yang dideritanya, berdasarkan gejala. Dari gejala-gejala yang timbul, ia kemudian akan mencari pertolongan ke tempat pengobatan yang dianggap dapat memulihkan kondisinya. Jika mereka kemudian tidak yakin dengan suatu jenis pengobatan tertentu, maka mereka akan mencoba untuk menggunakan jenis pengobatan lainnya.

\section{Tingkat keparahan penyakit}

Menurut James C. Young (Kasniyah 1983:28-33, Kasniyah 1983:34-39, Dyson 1988:21), tingkat keparahan penyakit merupakan bahan pertimbangan utama dalam pemilihan jenis perawatan kesehatan. Begitu juga dengan hasil penelitian yang dilakukan oleh Kasniyah dalam penanggulangan penyakit anak-anak pada masyarakat pedesaan Jawa pada tahun 1983 dan penelitian yang dilakukan Dyson mengenai pola tingkah laku masyarakat dalam mencari kesembuhan pada tahun 1988.

Pada kasus pemilihan penggunaan pengobatan transfer energi "A" sebagai alternatif atau komplementer dari pengobatan medis-modern juga dipengaruhi oleh tingkat keparahan penyakit yang dapat dilihat dari gejala penyakitnya dan lama menderita penyakit tersebut. Hal tersebut seperti dialami oleh informan " $\mathrm{C}$ " yang telah mengalami keluhan sakit di pinggang selama 13 tahun dan telah berobat dari pengobatan modern sampai berbagai metode pengobatan tradisional pernah dicoba namun belum kunjung membaik.

Tidak jauh berbeda dengan informan "E" yang telah menderita penyakit stroke selama 3 tahun mengakibatkannya mencari berbagai alternatif dan akhirnya menjatuhkan pilihannya kepada pengobatan transfer energi.

Kedua informan di atas menunjukkan bahwa penyakit yang dideritanya dianggapnya parah, karena penyakit yang diderita telah cukup lama, sehingga membuat mereka rela mengunjungi berbagai jenis pengobatan, baik medis-modern maupun tradisional, sampai menemukan jenis pengobatan yang cocok dan dapat menghasilkan kesembuhan.

\section{Kepercayaan atau keyakinan akan keefektifan pengobatan}

Salah satu kriteria yang digunakan seseorang untuk memilih jenis pengobatan ialah berdasarkan pada keyakinan akan keefektifan dari sistem perawatan kesehatan tersebut. Umumnya seseorang akan membandingkan keefektifan antara pengobatan yang satu dengan yang lain termasuk pengobatan tradisional dengan pengobatan medis-modern. Keyakinan tentang keefektifan suatu jenis pengobatan biasanya muncul dari pengalaman khusus, ataupun pengetahuan yang berkaitan dengan metode pengobatan tersebut, karena keyakinan atau kepercayaan dapat tumbuh jika berulangkali mendapatkan informasi yang sama (Sarwono 1993:14). Keputusan untuk melakukan pengobatan juga dibuat berdasarkan pada pengalaman dan kebiasaan seseorang di masa lalu. Oleh karena itu, keyakinan terhadap keefektifan pengobatan sifatnya sangat subjektif, bergantung pada pengalaman dan pengetahuan masing-masing individu.

Demikian halnya dengan pasien-pasien yang mendatangi pengobatan transfer energi, memiliki keyakinan sendiri-sendiri tentang jenis pengobatan yang dianggap dapat menyembuhkan penyakit 
yang dideritanya. Ada kalanya pengobatan medis-modern dianggap gagal sehingga lebih memilih pengobatan alternatif, walaupun tidak semua pengobatan alternatif yang tersebar di masyarakat mendatangkan kesembuhan. Keyakinan tersebut tumbuh berdasarkan pengalaman dan pengetahuan dari masing-masing informan. Misalnya saja, informan "E" yang memiliki kerabat atau teman yang mengalami penyakit yang sama seperti dirinya, tidak kunjung membaik walaupun melakukan pengobatan medis-modern. Berdasarkan pengalaman tersebut menumbuhkan keyakinan bahwa pengobatan medis-modern bukan merupakan jalan keluar utama ketika seseorang menderita sakit stroke. Terlebih lagi dalam masa penyembuhan diharuskan untuk mengkonsumsi obat-obatan, di mana nantinya dipercaya dapat merusak organ tubuh yang lain. Oleh karena itu, informan "E" lebih memilih untuk menggunakan pengobatan alternatif untuk menyembuhkan penyakitnya, walaupun ia juga selalu mencari berbagai jenis pengobatan alternatif sampai menemukan yang cocok dan kemudian dapat membawa perubahan ke arah yang lebih baik.

Beberapa informan mendatangi satu demi satu jenis pengobatan alternatif dengan harapan akan pulih seperti sedia kala. Dalam penggunaan pengobatan alternatif tersebut tentunya telah disertai adanya informasi mengenai metode pengobatan yang digunakan serta keberhasilan pengobatan tersebut. Salah satu informan yang merasa bahwa dengan pengobatan alternatif transfer energi kondisinya jauh lebih baik ialah informan "E". Ia merasa bahwa ruang geraknya sudah jauh lebih leluasa dibandingkan sebelumnya, setelah mengikuti dengan rutin terapi energi yang diberikan penyembuh dan anjuran untuk selalu menyeka bagian tubuh yang lumpuh karena stroke dengan air teh dan selalu minum air yang telah diberi energi pada saat terapi.

Berbeda halnya dengan informan " $\mathrm{H}$ ", ia tidak perlu untuk mencoba pengobatan ke beberapa alternatif terlebih dahulu. Ia memutuskan untuk melakukan pengobatan transfer energi dikarenakan telah mendengar metode yang digunakan dan dianggap tidak akan mempunyai dampak yang buruk bagi tubuh serta keberhasilan pengobatan tersebut terhadap penyakit yang tergolong berat, sehingga ketika anaknya menderita influenza yang dianggap sebagai penyakit ringan, ia memutuskan untuk melakukan pengobatan di sana.

Pengalaman secara langsung terhadap proses pengobatan yang mendatangkan keberhasilan membuat seseorang untuk mempunyai keyakinan terhadap keefektifan pengobatan tersebut. Hal tersebut yang mempengaruhi keluarga pasien untuk turut melakukan pengobatan serupa. Salah satu informan yang turut melakukan pengobatan dikarenakan keberhasilan anggota keluarganya adalah informan " $D$ " dan keluarga informan "E".

\section{Faktor ekonomi}

Faktor ekonomi mempunyai peranan besar dalam pengambilan keputusan akan pemilihan jenis perawatan kesehatan. Beralihnya penggunaan medis-modern ke pengobatan alternatif dikarenakan besarnya biaya yang harus dikeluarkan pasien ketika berobat ke rumah sakit, di samping itu walaupun banyak tersedia sarana-sarana kesehatan milik Pemerintah yang memberikan pelayanan gratis, tidak semua masyarakat menggunakan pelayanan tersebut, dikarenakan pelayanan gratis diidentikkan dengan pelayanan yang lambat, serta kurang memuaskan. Hal tersebut seperti disampaikan oleh informan "C" dan " $F$ ".

Pemilihan sumber perawatan kesehatan tradisional yang digunakan sebagai alternatif atau pelengkap medis-modern juga lebih selektif, karena ada sebagian yang memanfaatkannya untuk mencari keuntungan yang sebesar-besarnya, seperti yang dialami oleh informan " $\mathrm{C}$ " yang mengunjungi pengobatan tradisional untuk menghilangkan batu ginjal dengan metode bedah tanpa luka, ia dipungut biaya yang sangat besar untuk sekali pengobatan, bahkan terkesan menipu, karena setelah dilakukan bedah tersebut, batu yang dikeluarkan berupa batu pasir. Oleh karena itu, pada saat ia mendengar mengenai pengobatan alternatif " $A$ " dengan biaya sukarela, ia segera mendatanginya. Begitu juga halnya dengan informan "E", ia pernah merasa geram atas salah satu pengobatan tradisional yang menggunakan tenaga dalam, tetapi untuk penyakit tertentu, termasuk penyakit stroke yang dialaminya 
dikenakan tarif tinggi, setelah dilakukan pengobatan justru membuat informan masuk rumah sakit, karena saran yang tidak benar dari penyembuh.

Berdasar pada keterangan di atas, informan kemudian lebih selektif dalam memilih pengobatan, terlebih ia telah melakukan berbagai pengobatan dan mengeluarkan banyak biaya, sehingga ia lebih memilih pengobatan tradisional yang tidak dikenakan tarif dan bersifat sukarela, tidak seperti sebelumnya.

Pengobatan transfer energi " $A$ " yang tidak memungut biaya, baik terhadap penyakit berat atau ringan, anak kecil atau dewasa, membuat seseorang memilih untuk melakukan pengobatan di sana karena orang yang berobat bebas menentukan biaya pengobatan sesuai dengan kemampuannya. Hal tersebut seperti dikatakan oleh informan " $D$ ".

\section{Faktor sosial}

Dalam rangka menentukan jenis pengobatan yang akan dipilih, seseorang akan mencari informasi mengenai keberhasilan terhadap orang-orang yang mengalami gejala yang sama ketika melakukan pengobatan tersebut sebelumnya. Informasi tentang pengobatan tersebut diperoleh para informan melalui dua cara, yaitu: dorongan dari kerabat untuk menggunakan pengobatan tersebut, sehingga tidak sanggup menolak saran tersebut, dan/atau informasi didapatkan dengan cara getok tular.

\section{Dorongan Kerabat}

Foster dan Anderson (2006:49) menyatakan bahwa pada masyarakat non-Barat, pengambilan keputusan akan jenis perawatan kesehatan dipengaruhi oleh kerabat maupun orang-orang terdekat dari penderita sakit. Ketika salah satu anggota keluarga ada yang sakit, maka anggota keluarga yang lain serta orang-orang terdekat turut memberikan pilihan terhadap jenis pengobatan yang digunakan. Hal tersebut seperti dituturkan oleh informan "F", "G", "C", dan "H".

Berdasarkan keempat pernyataan di atas, terlihat bahwa pengambilan keputusan terhadap jenis pengobatan yang akan digunakan dipengaruhi oleh orang-orang di sekitar, bahkan tidak hanya sekedar saran, ia juga turut mengantarkan atau bahkan memperkenalkannya dengan penyembuh yang menggunakan metode transfer energi tersebut.

\section{Getok Tular}

Merupakan fakta bahwa masyarakat masih tetap mengunjungi pengobatan tradisional, baik sebagai pengganti atau alternatif maupun sebagai pelengkap pengobatan medis-modern (Soemowerdojo dalam Agoes 1996:108). Penggunaan pengobatan tersebut semakin luas dikarenakan proses sosialisasinya yang baik, dari mulai penyebaran informasi yang dilakukan media massa, tayangan televisi mengenai program bincang-bincang antara pasien dengan pelaku pengobatan tradisional, bahkan sampai informasi dari mulut ke mulut (Jawa:getok tular) yang dilakukan oleh pengguna pengobatan tersebut kepada keluarga, kerabat dan sebagainya.

Begitu pula dengan pengobatan transfer energi ini, diakui oleh penyembuh bahwa pasien yang datang untuk melakukan pengobatan kepadanya mendapat informasi dari orang yang pernah melakukan pengobatan tersebut. Pengakuan beberapa informan di bawah ini menunjukkan bahwa informasi mengenai pengobatan transfer energi didapatkan melalui mulut ke mulut. Pada informan pengguna pengobatan transfer energi, yaitu " $\mathrm{C}$ " mendapatkan informasi pengobatan tersebut dari pelanggan sayurnya. Menurut pelanggannya, pengobatan tersebut telah berhasil menyembuhkan anggota keluarganya. Hanya berdasarkan informasi tersebut, "C" segera mengunjungi tempat pengobatan tersebut. Pada pengalaman informan lainnya, yaitu " $D$ " yang mengetahui pengobatan tersebut secara tidak sengaja, karena ingin mendapatkan alamat pengobatan altenatif lain, tetapi justru mendapatkan 
informasi pengobatan transfer energi "A", kemudian ia mengajak ibunya untuk berobat ke sana, dan pada pengobatan berikutnya juga diikuti oleh anggota keluarga yang lain.

Informan "E" mendapatkan informasi mengenai pengobatan dengan menggunakan tenaga dalam di Tanggulangin dari anaknya, di mana anaknya juga mendapatkan informasi dari seorang temannya yang pernah melakukan pengobatan tersebut. Ia kemudian mengunjungi pengobatan tersebut, yang diketahui bahwa metode pengobatan yang digunakan adalah energi yang diambil dari bumi. Berbeda dengan ketiga informan di atas, informan " $\mathrm{F} 1$ " mendapatkan informasi dari rekan kerjanya, yang berprofesi sebagai guru di sebuah Sekolah Dasar, bahwa terdapat pengobatan yang menggunakan metode transfer penyakit ke hewan, berdasarkan informasi tersebut " $F 1$ " mengajak " $F$ " yang terserang penyakit kanker serviks dengan harapan penyakit ibunya dapat dipindahkan ke hewan, akan tetapi setelah beberapa kali berobat, pengobatan yang diberikan hanya transfer energi dari penyembuh ke tubuh pasien saja.

Berdasarkan keterangan tersebut, diketahui bahwa rekan kerja "F1" yaitu "H" juga mendapat informasi mengenai pengobatan tersebut dari rekan kantor suaminya yang menderita stroke, dan dapat pulih setelah beberapa kali terapi secara rutin. Atas dasar keberhasilan pengobatan tersebut, maka ketika anaknya sakit batuk yang tidak kunjung sembuh segera dibawa ke pengobatan transfer energi untuk mendapatkan terapi. Dari beberapa uraian cerita, semua informan dalam penelitian ini mendapatkan informasi pengobatan alternatif transfer energi dengan cara getok tular.

\section{Faktor jarak}

Faktor jauh atau dekatnya jarak antara tempat tinggal dengan sumber perawatan kesehatan akan mempengaruhi pengambilan keputusan dalam menentukan jenis pengobatan yang akan digunakan (Kasniyah 1983:34-39, Dyson 1988:21).

Berdasarkan keterangan dari informan diketahui bahwa pada umumnya, mereka telah mencoba ke berbagai pengobatan alternatif, baik di dalam kota sampai luar kota dan pengobatan yang dirasa cocok ialah ketika melakukan pengobatan di luar kota. Pada saat mendapatkan informasi mengenai jenis pengobatan ini, mereka tidak segan untuk mencobanya dengan pertimbangan-pertimbangan tertentu, termasuk jarak antara tempat tinggal dengan tempat pelayanan pengobatan yang lebih dekat dari sebelumnya. Hal tersebut dituturkan oleh informan "D" dan "E".

Berbeda dengan kedua informan di atas, oleh karena jarak antara rumah informan dengan tempat pelayanan pengobatan terbilang dekat, karena menurut pengamatan peneliti, lokasi dapat ditempuh kurang lebih 10 menit, informan "G" rela untuk 2 kali mengunjungi tempat pelayanan pengobatan dalam sehari dengan mengendarai sepeda motor, sekaligus membawa putri bungsunya "G2" yang saat itu sedang meningkat suhu tubuhnya untuk segera mendapatkan pengobatan. Hal tersebut menandakan bahwa jika jarak antara tempat tinggal dengan tempat pelayanan pengobatan jauh, tentunya informan tidak akan mengendarai sepeda motor dan rela dua kali pulang-pergi untuk berobat. Lokasi pengobatan yang dekat dengan tempat tinggal informan serta mudah dijangkau, membuat beberapa informan dengan mudah untuk mengunjunginya, baik dengan menggunakan kendaraan roda dua atau roda empat. Hal tersebut juga dilakukan oleh informan "E" yang menderita stroke, di mana setiap kunjungan berobat selalu diantar anggota keluarganya dengan kendaraan roda empat, ketika akan berobat berikutnya, mobil tersebut tidak bisa digunakan, maka ia rela diantar dengan sepeda motor untuk tetap menjalankan pengobatan sesuai dengan jadwal, walaupun pada saat tersebut sedang hujan deras. 


\section{Proses pengobatan}

Berdasarkan cara pengobatannya, pengobatan transfer energi apabila diklasifikasikan sesuai dengan Keputusan Menteri Kesehatan Republik Indonesia nomor 1076/MENKES/SK/VI tahun 2003 termasuk dalam pengobatan tradisional berdasarkan kekuatan supranatural, karena pengobatan dan/atau perawatannya menggunakan tenaga dalam, meditasi, olah pernafasan, indera keenam, dan kebatinan.

Pada teknik pengobatan transfer energi, pengobatan dilakukan oleh penyembuh pada organ yang sakit dengan membersihkan atau menghilangkan energi yang berpenyakit atau tidak dibutuhkan oleh tubuh pasien, kemudian memberikan energi yang dibutuhkan oleh tubuh pasien, terutama pada organ atau bagian tubuh yang dirasa sakit. Pemberian energi kepada seluruh bagian tubuh ini digunakan untuk memberikan keseimbangan pada tubuh. Pengobatan ini dapat diberikan kepada siapapun tanpa terkecuali, baik laki-laki atau perempuan, muda atau tua, kaya atau miskin, penyakit berat ataupun ringan.

Proses pengobatan transfer energi ini dilakukan oleh penyembuh dengan 3 cara, yaitu: (1) Proses pengobatan jarak dekat, yakni dengan bertatap muka antara penyembuh dengan pasien; (2) Proses pengobatan jarak jauh, yakni antara penyembuh dan pasien tidak bertemu secara langsung dan berada di lokasi yang berbeda; (3) Proses pengobatan dengan memindahkan penyakit ke hewan. Akan tetapi peneliti, hanya akan menggambarkan 2 (dua) proses pengobatan saja, yaitu proses pengobatan jarak dekat dan jarak jauh, hal tersebut dikarenakan selama melakukan penelitian, penulis tidak menjumpai proses pengobatan yang menggunakan media hewan dalam penyembuhannya.

Proses pengobatan jarak dekat dapat dijelaskan secara berurutan sebagai berikut: 1) pasien diperkenankan untuk duduk santai di ruang pengobatan, 2) penyembuh bertanya kepada pasien mengenai identitas dan keluhan mengenai kondisi kesehatan, 3) pasien menceritakan keluh kesah mengenai kondisi kesehatan yang dialaminya saat ini, 4) pasien diminta untuk menulis identitas dan keluhan kesehatan pada sebuah buku sebagai dokumentasi penyembuh, 5) pasien diminta untuk duduk di bangku panjang atau kursi plastik tanpa sandaran yang telah tersedia di ruang pengobatan guna memudahkan proses terapi, 6) pasien kemudian diajak oleh penyembuh untuk bersama-sama berdoa dalam hati sesuai dengan keyakinan masing-masing, memohon kesembuhan, 7) persiapan untuk terapi, di mana kondisi tubuh pasien harus dalam kondisi rileks, dan santai, 8) penyembuh lalu melakukan proses terapi dengan menyalurkan energi yang dibutuhkan pasien dan membuang energi yang tidak dibutuhkan pasien melalui telapak tangan yang disentuhkan atau terkadang seperti gerakan memijit dengan sedikit menekan pada bagian tubuh pasien yang dirasa sakit. Selain pada organ tubuh yang sakit, pemberian energi juga dilakukan pada bagian tubuh yang berkaitan dengan organ yang sakit tersebut.

Pemberian energi dilakukan secara berulang-ulang dan waktu yang dibutuhkan juga tidak terlalu lama. Pada saat proses terapi, penyembuh juga memberikan sugesti kepada pasien agar selalu mempunyai keinginan dan keyakinan untuk sembuh. Telapak tangan yang digunakan untuk memberikan energi tergantung pada penyembuh, karena kedua-duanya (kanan dan kiri) dapat digunakan untuk menyalurkan energi, akan tetapi bagi penyembuh lebih baik menyalurkan energi dengan menggunakan tangan kanan.

Pada saat terapi, penyembuh juga melakukan deteksi pada tubuh pasien mengenai keluhan yang dirasakan oleh pasien. Setelah dilakukan pendeteksian dengan dicocokkan dengan keluh kesah pasien, penyembuh menceritakan mengenai masalah kesehatan atau penyakit yang diderita pasien saat ini. Setelah dilakukan transfer energi, penyembuh bertanya kepada pasien bagaimana keadaannya. Terkadang untuk beberapa keluhan kesehatan, pasien diminta untuk mencoba menggerakkan anggota badan untuk mengetahui perubahannya dengan diberikan sugesti positif. Apabila dirasa masih terdapat gangguan, penyembuh akan memberikan energi pada bagian yang dirasa sakit dan kemudian menanyakan kembali kepada pasien sekaligus pasien dimohon untuk mencoba menggerakkan anggota badan sekali lagi, apakah keluhan yang dirasakan sebelumnya berangsur membaik. 
Setelah dirasa ada perubahan terhadap kondisi tubuh, pasien dipersilahkan untuk rileks sejenak. Penyembuh mengambil air mineral gelas yang telah disediakan oleh penyembuh di sudut ruangan dan memberikan doa untuk diberikan kesembuhan kepada orang yang bersangkutan sekaligus memberikan energi kepada air mineral tersebut. Pasien diminta untuk meminum air mineral tersebut. Selain air mineral gelas, pasien dianjurkan membawa pulang 2 botol air mineral berisi 1,5 liter yang sebelumnya air tersebut telah diberikan doa dan energi dengan harapan air tersebut dapat digunakan untuk membantu proses penyembuhan. Air mineral tersebut boleh dibawa dari rumah atau dapat dibeli di toko sekitar tempat pengobatan, atau dari penyembuh jika masih tersedia. Botol berisi air mineral yang siap untuk diminum ini dimaksudkan agar selalu dikonsumsi pasien selama proses pengobatan dan sebelum melakukan terapi berikutnya. Pasien diminta untuk kembali berobat sekitar 3-5 hari kemudian, karena setelah berobat sampai pada saat akan kembali berobat, penyembuh selalu memantau kondisi pasien, dan seringkali melakukan pengobatan jarak jauh (tanpa bertemu secara langsung) yang biasanya dilakukan pada malam hari.
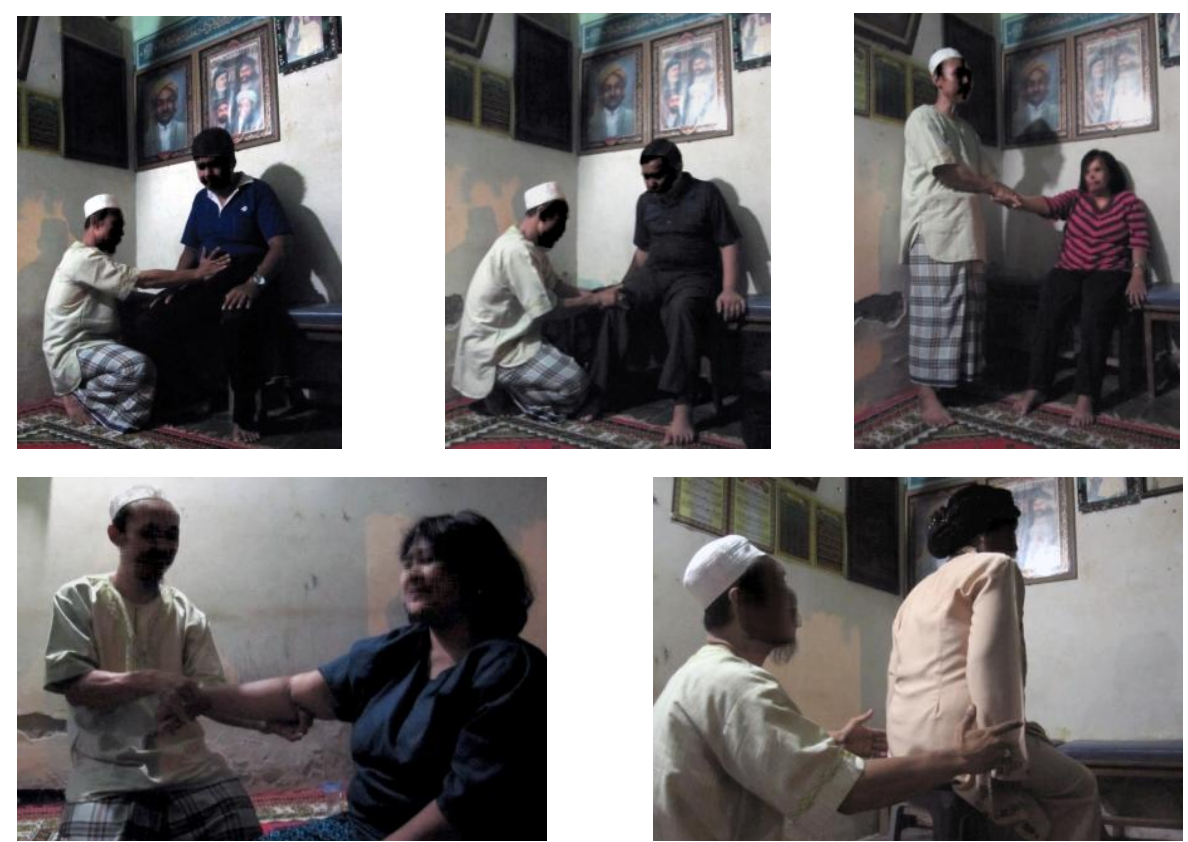

Gambar 1.

Proses pengobatan transfer energi jarak dekat Sumber: foto koleksi pribadi

Dalam proses pengobatan jarak jauh, hampir serupa dengan proses pengobatan jarak dekat, akan tetapi yang membedakannya adalah pasien dan penyembuh tidak bertemu secara langsung dan sekaligus berada di lokasi yang berbeda. Pengobatan jarak jauh ini dapat dilakukan ketika penyembuh saling berhubungan dengan pasien, dalam hal ini dapat melalui kontak telepon atau melalui foto pasien, di mana foto tersebut didapat dari keluarga pasien ketika datang ke penyembuh atau melalui surat yang dikirim lewat pos, yang disertai identitas serta kondisi/keluhan kesehatan pasien. Penyembuh dan pasien terhubungkan dengan mengarahkan pikiran penyembuh kepada pasien, karena energi prana pada umumnya dapat diarahkan dengan mengikuti ke mana pikiran atau perhatian penyembuh tertuju (jika penyembuh memusatkan perhatian kepada pasien, maka ia dapat membuang energi penyakit atau yang tidak dibutuhkan pasien dan menyalurkan energi yang dibutuhkan) (Sui 2006:252).

Jika pasien dalam keadaan tidak mengetahui bahwa dirinya dalam proses pengobatan, maka penyembuh berusaha membuat pasien turut merasakan adanya energi yang masuk ke dalam tubuhnya terutama pada organ/bagian tubuh yang sakit dengan ditandainya rasa nyeri atau otot tertarik atau kondisi yang berangsur membaik. Proses pengobatan jarak jauh dapat dijelaskan secara berurutan 
sebagai berikut: Pertama, penyembuh bertanya mengenai identitas dan keluhan kesehatan pasien; Kedua, pasien atau keluarga pasien menceritakan mengenai kondisi kesehatan; Ketiga, jika melalui kontak telepon pasien diminta untuk berdoa bersama dalam hati dengan tujuan memohon untuk kesembuhan pasien; Keempat jika melalui kontak telepon proses persiapan terapi, dengan meminta pasien untuk rileks dan santai; Kelima proses terapi dilakukan dengan menyebutkan identitas pasien, melihat foto (atau bisa melalui kontak telepon) dan berkonsentrasi untuk menyalurkan energi yang dibutuhkan pasien dan membuang energi yang tidak dibutuhkan pasien, terutama pada bagian tubuh pasien yang dirasa sakit. Selain pada organ tubuh yang sakit, juga diberikan kepada bagian tubuh yang berkaitan dengan organ tersebut. Terapi atau pemberian energi dilakukan secara berulang-ulang. Pada saat proses terapi, penyembuh juga memberikan sugesti kepada pasien agar selalu mempunyai keinginan dan keyakinan untuk sembuh; Keenam, setelah dilakukan terapi, penyembuh selalu bertanya kepada pasien bagaimana keadaannya. Apabila dirasa masih terdapat gangguan, maka akan dilakukan terapi beberapa kali hingga pasien merasakan bahwa lebih baik dari sebelumnya; Ketujuh, pasien dipersilahkan untuk menyiapkan air minum satu gelas dan 2 botol berukuran 1,5 liter, yang akan diberikan energi dan doa untuk kemudian diminum; Kedelapan, pasien diminta untuk menghubungi penyembuh setelah 3 hari, untuk mengetahui perkembangan kesehatan dan terapi.

Proses pengobatan jarak jauh ini juga digunakan sebagai lanjutan proses pengobatan, di mana penyembuh melakukan pengobatan ulang setelah pengobatan secara langsung, dalam masa sebelum pasien kembali untuk berobat pada 3-5 hari kemudian. Hal tersebut dilakukan dengan cara penyembuh berkonsentrasi dengan membayangkan atau melihat foto pasien dan menyebut nama pasien, kemudian melakukan transfer energi yang dibutuhkan pasien terutama pada bagian tubuh/organ yang sakit. Pemberian energi bukan ditujukan untuk foto tersebut, melainkan untuk tubuh pasien, oleh karena itu penting sekali dalam proses pengobatan jarak jauh untuk menyebutkan seluruh identitas pasien, yang meliputi nama lengkap, tanggal lahir, dan alamat pasien sebelum melakukan terapi. Hal tersebut dilakukan agar energi yang penyembuh berikan dapat sampai ke tujuan dan tidak menyasar ketempat lain, karena terkadang ada kemungkinan bahwa beberapa orang mempunyai nama yang sama, sehingga agar perawatan yang dilakukannya sampai ketujuan perlu juga ditanyakan tanggal lahir pasien itu. Walau sangat kecil, masih ada kemungkinan ada orang dengan nama yang sama dan dilahirkan pada tanggal yang sama, jadi diperlukan informasi tambahan yang ketiga, yaitu alamat. Hampir tidak mungkin ada orang dengan nama yang sama, tanggal lahir yang sama dan tinggal di rumah yang sama pula. Akan tetapi, penyebutan identitas ini hanya dilakukan di awal terapi, dan ketika terapi berikutnya penyembuh hanya menyebutkan nama pasien saja.

Pengobatan jarak jauh ini banyak dilakukan pada malam atau dini hari ketika pasien sedang terlelap karena dianggap lebih efektif bagi pasien untuk menerima energi yang diberikan oleh penyembuh, di mana pasien tidak sedang melakukan aktifitas yang kemudian dapat berdampak bagi pemberian energi yang dilakukan penyembuh. Penyembuh menghentikan pengobatan tersebut pada saat menjelang fajar. Hal tersebut dilakukan agar penyembuh dapat beristirahat untuk beraktifitas keesokan pagi dan di samping itu, menurut Choa Kok Sui dalam bukunya menyebutkan bahwa energi prana lebih lemah, karena sekitar pukul tiga atau empat dini hari merupakan tingkat terendah perolehan energi tersebut (Widayati 1999:29, Sui 2006:5).

Proses penyembuhan akan lebih mudah jika pasien bersikap rileks dan mau menerima atau tidak memberikan penolakan terhadap jenis pengobatan tersebut. Jika pasien rileks serta mau menerima, tubuhnya dapat menyerap lebih banyak energi, hal tersebut seperti yang disampaikan oleh "A", selaku penyembuh bahwa ketika pasien percaya terhadap pengobatan ini, maka energi yang disalurkan oleh penyembuh dapat diterima pasien dengan baik, akan tetapi jika pasien mempunyai keraguan, maka energi tersebut akan kembali kepada penyembuh. Penolakan energi prana untuk masuk ke dalam tubuh pasien, dikarenakan beberapa alasan, yaitu: pertama, jika pasien mempunyai prasangka buruk terhadap jenis penyembuhan seperti ini, jika pasien tidak menyukai pribadi penyembuh, dan ketiga, jika pasien tidak ingin sembuh (Sui 2006:77). Oleh karena itu, hubungan baik antara penyembuh dengan pasien harus terjalin dengan baik untuk mengurangi adanya penolakan energi dari pasien. 
Seorang penyembuh ketika melakukan proses pengobatan haruslah benar-benar konsentrasi dan rileks ketika menyalurkan energi ke tubuh pasien, walaupun seringkali diselingi guyonan kepada pasien. Hal tersebut dilakukan penyembuh agar hubungan pasien dan penyembuh lebih akrab, dan pasien tidak terlalu stress.

Ketika proses pengobatan, penyembuh turut merasakan kondisi yang diderita oleh pasien, walaupun penyembuh seringkali menanyakan kondisi pasien sebelumnya. Menurut "A", hal tersebut dilakukan untuk memastikan apakah benar diagnosa dari penyembuh sesuai dengan apa yang dialami pasien. Diagnosa oleh penyembuh ini didasarkan pada salah satu dari tiga metode utama, yaitu pengetahuan intuitif yang diperoleh melalui meditasi. Diagnosa oleh penyembuh dapat didasarkan pada salah satu atau kombinasi dari numerologi (Jawa:petungan), pengetahuan secara intuitif melalui meditasi, dan penganalisaan simtom-simtom (Geertz 1989:123).

Pada proses pengobatan transfer energi ini, pengetahuan tersebut diketahui ketika penyembuh mulai menyalurkan energi prana secara menyeluruh kepada tubuh pasien. Penyembuh dapat merasakan dan mengalami keadaan pasien, bahkan mengetahui bahwa pasien pernah mengalami suatu hal yang menyebabkan kondisi tubuh tidak benar. Begitu juga pada saat proses pengobatan, pasien juga dapat merasakan efek dari pengobatan tersebut, seperti rasa nyeri atau kesakitan pada daerah yang diberikan energi prana dengan cara disentuh dengan sedikit ditekan. Hal tersebut tampak pada saat proses pengobatan yang dilakukan pada salah seorang pasien, di mana penyembuh mengetahui bahwa pada bagian tulang punggung pasien ada yang tidak beres, dikarenakan pasien pernah jatuh atau terbentur secara keras. Pasien tersebut merupakan salah satu keluarga informan, yang kemudian membenarkan bahwa beberapa hari lalu pada saat mengendarai sepeda motor melewati jalan yang berlubang, dan karena shock absorber kendaraan tidak berfungsi maka badan terasa terhantam oleh jok motor. Ketika energi prana disalurkan ke daerah tersebut dengan tujuan untuk mengembalikannya ke keadaan semula, raut wajah pasien terlihat berubah, karena menahan rasa sakit. Selain rasa nyeri yang dirasakan, beberapa pasien juga merasakan kehangatan dibagian tubuh yang dialiri energi oleh penyembuh pada saat proses pengobatan berlangsung.

Dalam proses pengobatan, selain pasien diberikan sugesti agar mempunyai keinginan untuk sembuh, pasien harus memiliki kepercayaan dan keyakinan, bahwa melalui pengobatan dan perantara penyembuh dan air yang diminum dapat mendatangkan kesembuhan bagi dirinya. Oleh karena itu, selain proses pengobatan dengan memberikan dan mengeluarkan energi, baik yang diperlukan atau tidak dibutuhkan oleh tubuh, pasien juga diberikan air mineral yang telah diberikan doa dan energi. Pemilihan air mineral (siap minum) sebagai media penyembuhan dikarenakan air mineral tidak memberikan dampak negatif terhadap tubuh, karena sesungguhnya dengan minum air mineral sangat baik bagi tubuh. Pemberian doa pada air mineral tersebut diucapkannya dalam hati sekaligus berkonsentrasi untuk memberikan energi dengan menyebutkan nama pasien yang akan minum air tersebut. Oleh karena, air mineral tersebut telah diyakini oleh pasien dapat membantu proses penyembuhan, pasien dengan leluasa memanfaatkan air mineral tersebut untuk diminum atau juga dioleskan atau dibasuhkan kepada bagian tubuh yang sakit.

\section{Simpulan}

Beragamnya jenis pelayanan kesehatan yang tersedia di masyarakat membuat seseorang dapat menentukan jenis pengobatan yang akan dilakukannya untuk mencari kesembuhan. Berdasarkan hasil penelitian yang dilakukan kepada beberapa informan ketika berkunjung ke pengobatan transfer energi "A", diketahui bahwa faktor pengetahuan akan jenis dan metode pengobatan yang akan digunakan sebelumnya, membuat mereka merasa aman untuk memilih pengobatan tersebut. Keberhasilan pengobatan terhadap jenis penyakit yang diderita serta keyakinan terhadap pengobatan transfer energi membuat informan kembali melakukan pengobatan tersebut hingga sembuh, atau bahkan tak segan untuk kembali berobat ketika menderita penyakit lain atau serupa. Selain itu, yang menjadi bahan pertimbangan adalah tingkat keparahan akan penyakit yang diderita, karena pada umumnya mereka 
telah mendatangi berbagai pengobatan, namun tak kunjung membaik, maka ketika mendapatkan informasi mengenai keberhasilan pengobatan tersebut, mereka beralih dan kemudian berobat kepadanya.

Faktor yang kedua adalah faktor ekonomi, di mana informan memilih menggunakan pengobatan transfer energi didasarkan pada terjangkaunya biaya pengobatan, di mana pada pengobatan tersebut tidak diberlakukan tarif pengobatan, sehingga informan bebas menentukan biaya pengobatan sesuai dengan kemampuan dan keikhlasannya.

Faktor ketiga pemilihan penggunaan jenis pengobatan transfer energi dipengaruhi oleh faktor sosial yang terdiri dari dorongan kerabat serta informasi yang didapatkan oleh informan secara getok tular. Dorongan kerabat terhadap informan didasarkan atas keberhasilan pengobatan, baik melalui pengalaman secara pribadi ketika ia melakukan pengobatan tersebut atau hanya berdasarkan informasi dari mulut ke mulut oleh orang yang pernah berobat di sana atau bahkan dari orang lain yang belum pernah melakukan pengobatan tersebut. Selain ketiga faktor di atas, jarak antara rumah informan dengan tempat pengobatan yang terbilang dekat, karena sama-sama berada di dalam kota, sehingga dapat ditempuh rata-rata sekitar 10-15 menit, juga menjadi latar belakang pengambilan keputusan ketika akan berobat di sana, karena dengan jarak yang dekat, informan dapat memilih jenis kendaraan yang akan digunakannya.

Proses pengobatan transfer energi yang menggunakan energi dari bumi, terbagi menjadi 3 cara, yaitu pengobatan jarak dekat, jarak jauh, dan pemindahan penyakit kepada hewan. Proses pengobatan jarak dekat, dapat diuraikan sebagai berikut: pertama, penyembuh harus mengenal dan mengetahui keluhan pasien, kemudian dilakukan terapi dengan memindahkan energi positif yang berasal dari energi matahari, udara, atau air dari tubuh penyembuh ke tubuh pasien sebatas yang dibutuhkan oleh pasien, kemudian mengeluarkan energi negatif yang tidak dibutuhkan pasien. Setelah dilakukan terapi, penyembuh memberikan tambahan energi melalui air mineral yang akan dikonsumsi pasien selama masa penyembuhan, di mana energi tersebut juga diberikan doa dengan harapan pasien segera mendapat kesembuhan. Untuk jenis penyakit berat, proses terapi harus diulangi kembali pada 3 sampai 5 hari kemudian.

Proses pengobatan jarak jauh dilakukan dengan tidak bertatap muka antara penyembuh dengan pasien, atau ketika berada pada lokasi yang berbeda. Pengobatan jarak jauh dapat melalui kontak telepon atau foto pasien. Pengobatan jarak jauh juga dilakukan pada saat proses penyembuhan ketika masa menunggu pasien untuk terapi selanjutnya. Proses tersebut hampir sama seperti pengobatan jarak dekat, namun yang membedakannya adalah penyembuh dan pasien tidak bertemu secara langsung. Untuk proses pengobatan dengan memindah penyakit ke hewan tidak dapat dijelaskan, karena peneliti tidak menemukan secara langsung pengobatan tersebut selama masa observasi dan wawancara dilakukan di lokasi penelitian.

\section{Daftar Pustaka}

Agoes A (1996) Pengobatan tradisional di Indonesia. Dalam Agoes dan Jacob (eds). Antropologi Kesehatan Indonesia Jilid 1. Jakarta: Penerbit Kedokteran EGC.

Departemen Kesehatan Indonesia (2003) Keputusan Menteri Kesehatan Indonesia nomor 1076/MENKES/SK/VII/2003 tentang Penyelenggaraan Pengobatan Tradisional.

Dyson L, Glinka J, Trijoko S, Adam S, \& Rustinsyah (1988) Pola tingkah laku masyarakat dalam mencari kesembuhan (Berobat). Surabaya: Lembaga Penelitian Universitas Airlangga.

Foster GM, \& Anderson BG (1986) Antropologi kesehatan. Jakarta: Universitas Indonesia press.

Geertz C (1989) Abangan, santri dan priyayi dalam masyarakat Jawa. Jakarta: Pustaka Jaya.

http://cybertech.cbn.net.id/cbprtl/cybermed/detail.aspx?x=Alternatif\&y=cybermed|0|0|2|20 [diakses 2 Oktober 2014]. 
Kasniyah N (1983) Pengambilan keputusan dalam pemilihan sistem pengobatan khususnya penanggulangan penyakit anak-anak (Balita) pada masyarakat pedesaan Jawa. Jakarta: Fakultas Pascasarjana Universitas Indonesia. Tesis tidak diterbitkan.

Lumenta B (1989) Pasien, citra, peran dan perilaku: tinjauan fenomena sosial. Yogyakarta: Kanisius.

Sarwono S (1993) Sosiologi kesehatan-beberapa konsep dan aplikasinya. Yogyakarta: Gadjah Mada University Press.

Soemowerdojo S (1996) Kedudukan paranormal, metafisika dan mistik. Dalam Agoes dan Jacob (eds). Antropologi Kesehatan Indonesia Jilid 1. Jakarta: Penerbit Kedokteran EGC.

Sui CK (2006) Mukjizat penyembuhan prana. Jakarta: PT. Elex Media Komputindo.

Weiss GL dan Lonnquist LE (1996) The sosiology of health, healing, and illness. New Jersey: Prentice-Hall, Inc.

Widayati R (1999) Penyembuhan dengan tenaga prana. Surabaya: Fakultas Ilmu Sosial dan Ilmu Politik Universitas Airlangga. Skripsi Tidak diterbitkan. 